\title{
Pendampingan Diversifikasi Produk Olahan Tape Pada UMKM Pembuat Tape "Ngangeni" di Dusun Mangli Desa Karangsari Kecamatan Sempu Banyuwangi
}

\author{
Nunuk Nurchayati ${ }^{1}$, Novi Prayekti ${ }^{2}$, Hasyim As'ari ${ }^{3}$ \\ Faculty of Mathematic and Natural Science, Universitas PGRI Banyuwangi \\ nnurchayati99@gmail.com
}

\begin{abstract}
Abstrak
Dusun Mangli merupakan daerah di Desa Karangsari Kecamatan Sempu Banyuwangi yang penduduknya banyak sebagai pelaku UMKM pengusaha tape. Para pengusaha tape dari dusun Mangli ini menjual tape hasil produksinya dalam bentuk setengah jadi dan dikirim ke Bali atau di jual di area lokal. Produksi tape ini sangat dipengaruhi oleh keberadaan singkong sebagai bahan bakunya. Jika harga singkong murah para pengusaha tape memperbesar produksi dan berakibat banyak tape yang tidak laku terjual. Sebaliknya jika harga singkong mahal maka, pengusaha tape memilih tidak memproduksi. Tape yang tidak laku jual dan produksi yang tersendat menyebabkan pendapatan masyarakat sekitar juga menurun. Melihat kondisi tersebut tim pengabdian masyarakat fakultas MIPA Universitas PGRI Banyuwangi melakukan pendampingan diversifikasi produk olahan tape pada UMKM pembuat tape "Ngangeni" di Dusun Mangli tersebut. Tujuannya adalah agar pengusaha tape dapat meningkatkan nilai ekonomi tape dengan memanfaatkan tape yang tidak laku jual dan dapat lebih berdaya dalam meningkatkan perekonomian. Kegiatan Pengabdian kepada Masyarakat ini dilakukan dalam beberapa tahapan yaitu perencanaan, pelaksanaan pelatihan pembuatan produk olahan, pendampingan pembuatan produk, pengemasan dan pemasaran, evaluasi dan monitoring. Hasil dari kegiatan menunjukkan adanya peningkatan pengetahuan pelaku UMKM pembuat tape untuk mengolah tapenya menjadi produk bernilai jual. Produk dari yang dijual juga beragam tidak hanyak tape. Pelaku UMKM juga menjadi berdaya untuk meningkatkan nilai ekonomis tape.
\end{abstract}

Kata Kunci: Tape singkong, diversifikasi, produk olahan.

\begin{abstract}
Mangli is an area in Karangsari Village, Sempu Banyuwangi Subdistrict, which has many residents as tape entrepreneurs. These tape entrepreneurs from Mangli sell their production tape in semi-finished form and send it to Bali or sell it in the local area. The production of tape is influenced by the cassava as its raw material. If the prices of cassava is cheap, tape businessmen increase production and it's cause many tapes that are not sold. Conversely, if the price of cassava is expensive, tape entrepreneurs choose not to produce. Tape that is not selling and production is stagnant causes the income of the surrounding community to decline. Based this condition, the MIPA faculty community service team at PGRI Banyuwangi University provided assistance in diversifying processed tape products to UMKM of "Ngangeni" tape in the Mangli. The purpose is in order tape entrepreneurs can increase the economic value of tape by utilizing tape that is not selling well and can be more powerful in improving the economy. The Community Service activities are carried out in several stages, namely planning, training in making processed
\end{abstract}


products, assisting in product manufacturing, packaging and marketing, evaluation and monitoring. The results of the activity showed an increase in knowledge of UMKM tape makers to process their products into a selling value product. Products from the sale also vary not only tape. UMKM also become empowered to increase the economic value of tape.

Keywords: Cassava tape, Diversification, Processed product

\section{PENDAHULUAN}

Tape merupakan makanan tradisional popular di Pulau Jawa. Berdasarkan bahan bakunya, ada dua jenis tape, yaitu tape ketan dan tape singkong. Tape ketan berasal dari beras ketan (Oryzae sativa Var. Glutinosa). Tape singkong berasal dari umbi tanaman singkong (Manihot utilissima). Keduanya melalui proses fermentasi oleh ragi mikroba Schharomyces cereviceae. Akibat fermentasi tersebut diperoleh tape dengan tekstur yang lembek dan halus. Kandungan gizi pada tape singkong meliputi i(172 kkal), protein (0,5 gram), karbohidrat (42,5 gram), lemak (0,1 gram), kalsium (30 miligram), fosfor (30 miligram), vitamin (0,07 miligram). Beberapa daerah di Jawa Timur banyak menghasilkan tape dan memanfaatkannya untuk berbagai kepentingan. Salah satunya di Dusun Mangli Desa Karangsari Kecamatan Sempu Kabupaten Banyuwangi.

Di dusun Mangli ini hampir sebagian besar warganya memiliki usaha pembuatan tape tradisional. Berdasarkan testimoni dari beberapa konsumen, tape dari dusun Mangli memiliki rasa yang manis sehingga sangat tepat dijadikan sebagai campuran dalam pembuatan kue. Tetapi kebanyakan pengusaha pembuat tape tradisional dari dusun Mangli hanya menjual tape secara langsung atau dalam kondisi setengah jadi tanpa diolah menjadi produk turunan yang lebih menarik. Salah satu pengusaha pembuat tape tradisional di Dusun Mangli yang banyak menyerap tenaga kerja adalah Bapak Amrodiyanto pemilik usaha tape "Ngangeni”. Beliau menjadi pengusaha tape selama 10 tahun. Tape yang dibuatnya banyak dijual di area sekitar ataupun ke Bali. Setiap kali produksi tape melimpah maka menyebabkan tape banyak tidak laku dan harus dibuang percuma karena tidak diolah menjadi produk turunan. Melalui kegiatan Pengabdian Masyarakat ini, maka dilakukan kegiatan pendampingan dan pelatihan pembuatan ragam makanan olahan berbahan dasar tape singkong yang memiliki nilai jual di masyarakat.

\section{METODE PELAKSANAAN}

Kegiatan pengabdian masyarakat ini dilaksanakan selama 5 bulan mulai April 2019 sampai Agustus 2019 di Dusun Mangli Desa Karangsari Kecamatan Sempu 
Kabupaten Banyuwangi. Rencana kegiatan yang dilakukan meliputi beberapa tahapan, yaitu perencanaan, pelaksanaan, evaluasi dan monitoring.

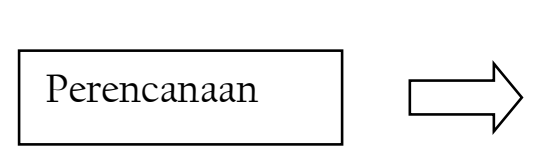

Pelaksanaan

Praktek
mandiri

\begin{tabular}{|l|}
\hline $\begin{array}{l}\text { Pendampingan } \\
\text { pengemasan } \\
\text { dan pemasaran }\end{array}$ \\
\hline
\end{tabular}

\begin{tabular}{|l|}
\hline $\begin{array}{l}\text { Evaluasi dan } \\
\text { Monitoring }\end{array}$ \\
\hline
\end{tabular}

1. Koordinasi dengan mitra

2. Membuat perencanaan produk yang akan dilatihkan pada mitra

3. Membuat buku resep untuk masing-masing produk

1. Melakukan penyuluhan tentang nilai gizi tape singkong dan manfaatnya untuk ragam olahan

2. Memberi pelatihan pembuatan produk ( prol tape, ladrang tape dan stick tape)

1. Mitra melakukan praktek mandiri pembuatan produk

2. Melakukan pendampingan terutana pada kulitas produk hasil praktek mandiri

Melakukan pendampingan tentang pengemasan yang menarik dan cara pemasaran yang efektif

1. Evaluasi kegiatan mitra

2. Monitoring keberlanjutan kegiatan mitra

Gambar 1. Tahapan Kegiatan Pengabdian Kepada Masyarakat

Tahap persiapan dan perencanaan diawali dengan dilakukannya pemilihan mitra. Mitra dipilih berdasarkan tenaga kerja yang dimilikinya dan juga kesanggupannya untuk menjadi mitra. Mitra memiliki tenaga kerja yang lebih banyak yaitu sekitar 23 orang. Sehingga harapannya dengan bertambahnya produk olahan yang mampu dihasilkan, maka dapat menyerap tenaga kerja lebih banyak. Selanjutnya dilakukan perencanaan produk yang akan dilatihkan kepada mitra yaitu meliputi prol tape, ladrang tape dan stick tape. Pemilihan produk tersebut berdasarkan pertimbangan cara pembuatannya yang mudah dan produknya banyak digemari dari berbagai kalangan. Selanjutnya dibuat buku 
resep yang dapat digunakan sebagai acuan bagi mitra untuk melakukan uji coba pembuatan produk.

Tahap pelaksanaan kegiatan Pengabdian Kepada Masyarakat ini diawali dengan penyuluhan kepada mitra tentang kandungan dan nilai gizi dari tape singkong. Selanjutnya dilakukan pelatihan pembuatan produk berupa prol tape, ladrang tape, dan stick tape. Mitra juga dibekali buku resep agar mitra dapat lebih menguasai pembuatan produk.

Selain itu tim Pengabdian Kepada Masyarakat juga member kesempatan kepada mitra untuk melakukan praktek mandiri pembuatan produk. Tim Pengabdian Kepada Manyarakat juga melakukan pendampingan terhadap kegiatan mitra saat melakukan pembuatan produk secara mandiri. Pendampingan dilakukan berkala selama satu minggu dan meliputi kualitas produk dan cara pengemasan produk agar menarik.

Tahap berikutnya adalah melakukan evaluasi dan monitoring. Evaluasi dilakukan terhadap pelaksanaan dan keberlanjutan produksi dan penjualan produk oleh mitra. Tujuannya untuk mengetahui efektifitas terhadap kegiatan pendampingan yang dilakukan. Monitoring dan evaluasi dilakukan oleh tim Pengabdian Kepda Masyarakat secara berkala yaitu setiap minggu dengan komunikasi dengan mitra baik dengan ketemu secara langsung ataupun menggunakan sarana komunikasi (telepon, sms, whatsapp atau email). Setiap kegiatan dilakukan dokumentasi.

\section{HASIL DAN PEMBAHASAN}

Mitra pada kegiatan Pengabdian Kepada Masyarakat ini merupakan pelaku UMKM pengusaha tape tradisional yang menjual tapenya tanpa melalui upaya pengolahan menjadi produk turunan. Proses pembuatan tape juga dilakukan dengan cara sederhana.
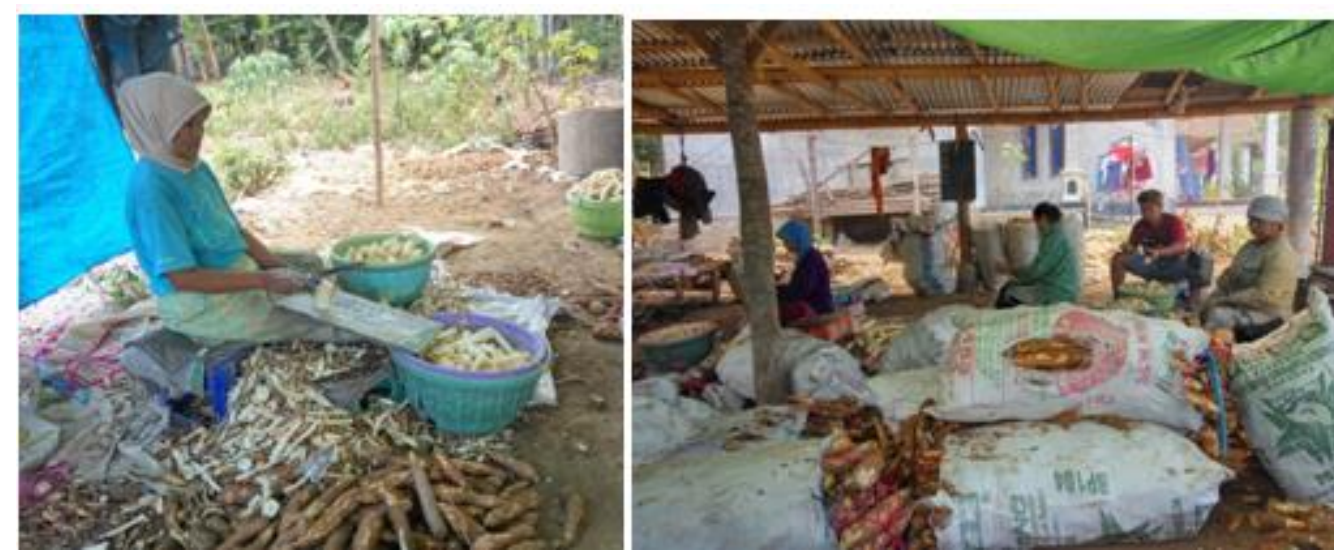

Gambar l. Foto Kegiatan Pengupasan Singkong Saat Pembuatan Tape Singkong di Tempat Mitra 
Permasalahan utama yang dihadapi oleh mitra adalah belum dimilikinya pengetahuan untuk mengolah tape singkong hasil olahannya menjadi produk turunan yang bernilai jual. Sehingga ketika produksi melimpah menyebabkan banyak tape harus kembali tidak laku dan dibuang percuma. Kegiatan pengabdian yang telah dilakukan adalah sebagai berikut.

Tahapan kegiatan pengabdian kepada masyarakat ini diawali dengan kegiatan perencanaan yaitu menentukan produk yang akan dilatihkan mitra. Produk tersebut meliputi prol tape, ladrang tape dan stick tape. Semua produk tersebut dibuat suatu buku resep untuk memudahkan mitra dalam membuat produk dan sebagai referensi jika ada kejenuhan terhadap resep yang telah dilatihkan.
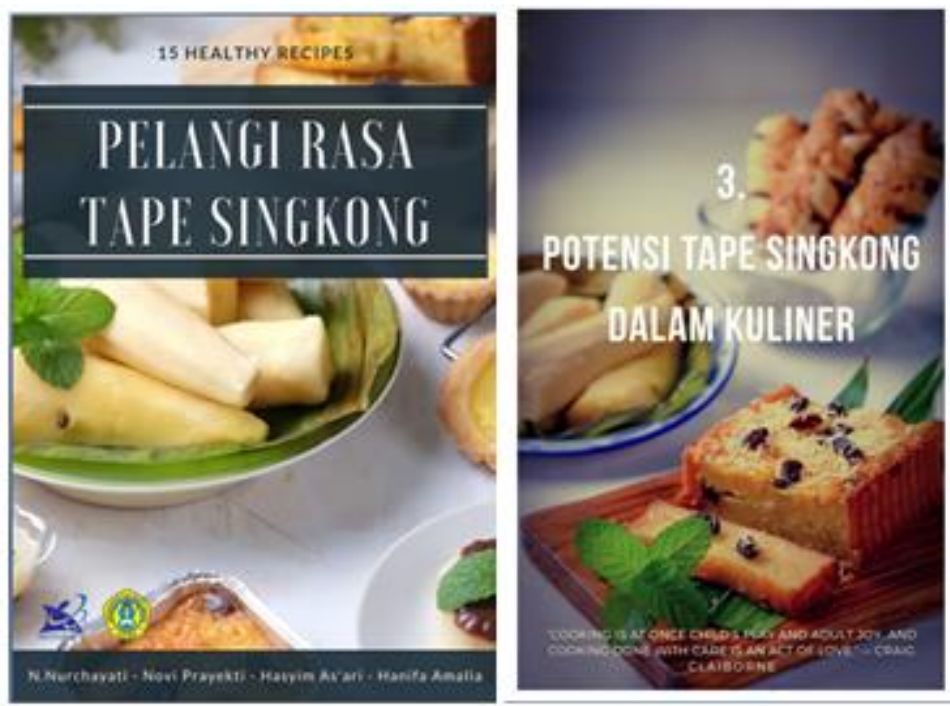

Gambar 2. Sampul Buku Resep yang Dibuat Untuk Mitra

Tahap pelaksanaan dari kegiatan pengabdian kepada masyarakat ini dilakukan dengan pelatihan kepada mitra cara pembuatan produk olahan prol tape, ladrang tape dan stick tape. 

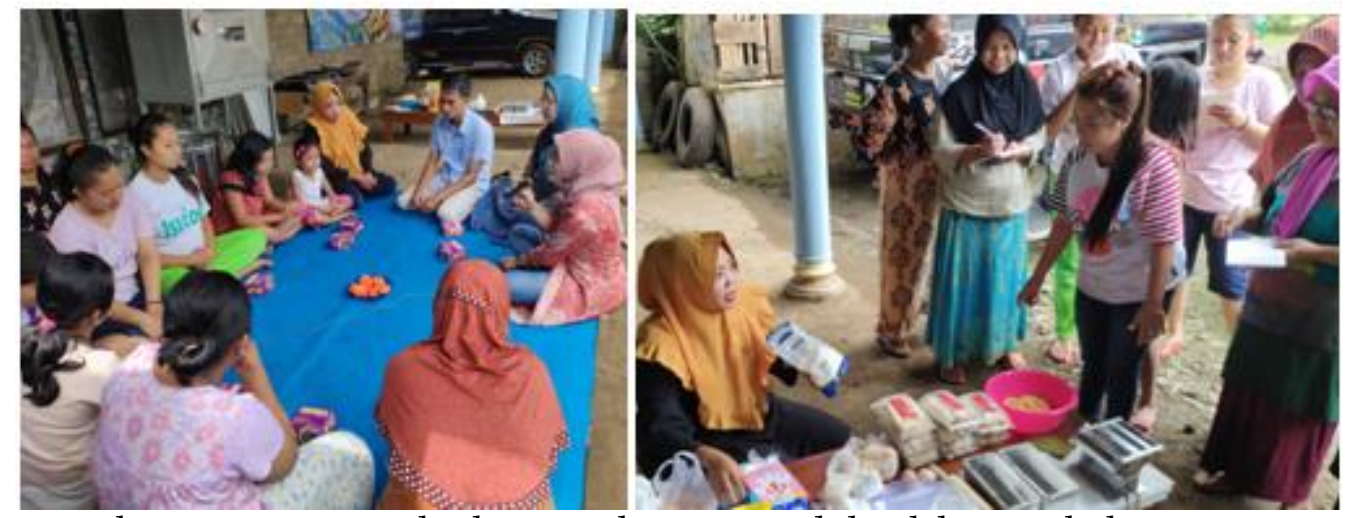

Gambar 3. Kegiatan Pelatihan Pembuatan Produk Olahan Berbahan Dasar

Tape

Selanjutnya mitra melakukan praktek mandiri membuat produk olahan. Setelah praktek mandiri, tim Pengabdian Kepada Masyarakat melakukan pendampingan terhadap kualitas produk. Tim Pengabdian Kepada Masyarakat juga melakukan pendampingan pada pengemasan produk yang menarik minat pasar. Tim Pengabdian Kepada Masyarakat juga melakukan penjelasan tentang pengajuan PIRT produk Selain itu juga dilakukan pendampingan manajemen pemasaran produk..

Mitra melakukan pemasaran awal terhadap produk di toko terdekat. Harga penjualan produk berkisar 15.000 sampai 17.000. Tentunya produk ini dapat meningkatkan harga jual tape yang semula 3000 sampai 4000 per kg. Selanjutnya tim Pengabdian Kepada Masyarakat menyarankan untuk melakukan pemasaran di toko oleh-oleh dan juga melewati toko online. Evaluasi dan monitoring kegiatan dilakukan tiap minggu untuk memantau keberlanjutan dari produksi produk-produk turunan dari tape singkong tersebut.
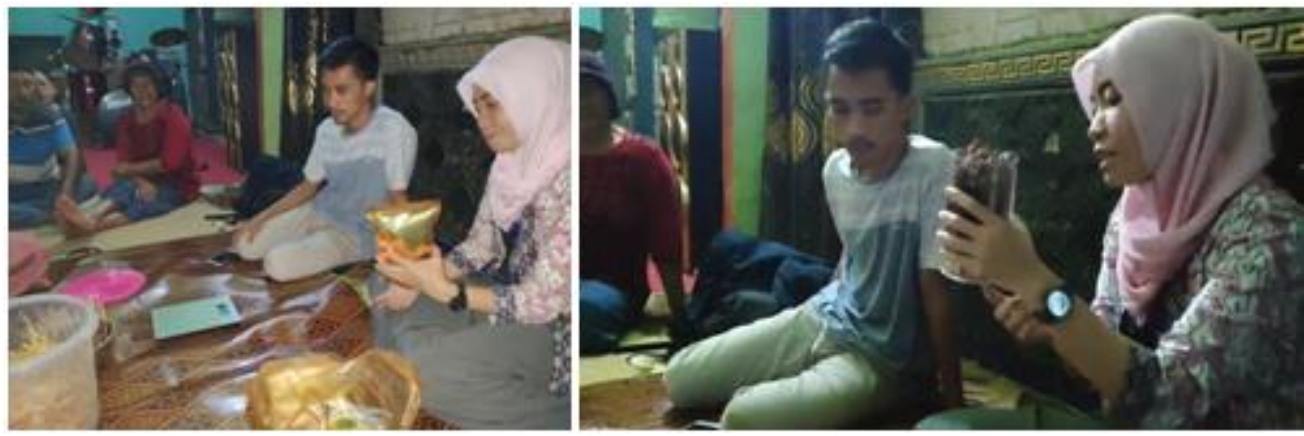

Gambar 4. Proses Pendampingan Pengemasan 

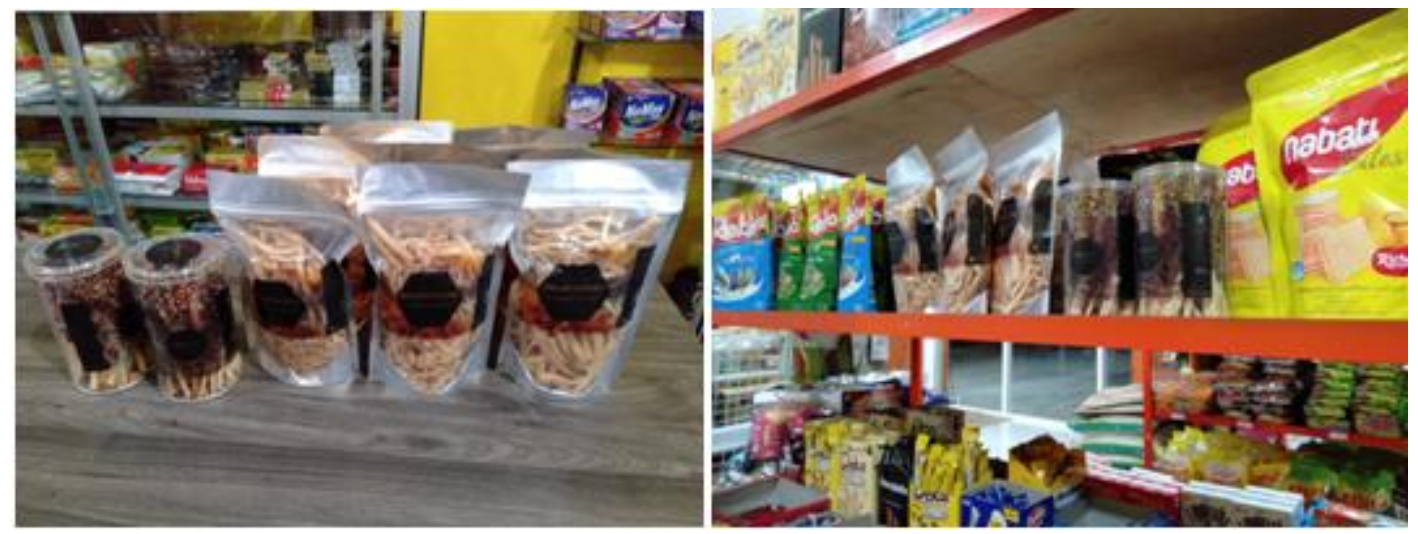

Gambar 5. Produk yang Telah Dikemas dan Dipasarkan

\section{KESIMPULAN DAN SARAN}

Kesimpulan dari kegiatan pengabdian kepada masyarakat dengan judul "Pendampingan Diversifikasi Produk Turunan Tape pada UMKM Pembuat Tape Tradisional di Dusun Mangli Desa Karangsari Kecamatan Sempu Kabupaten Banyuwangi" ini berhasil :

1. Memberikan pengetahuan kepada pelaku UMKM untuk mengolah produk tape menjadi olahan yang bernilai jual.

2. Memberdayakan pelaku usaha tape singkong untuk melakukan diversifikasi produk olahan dari tape singkong, sehingga tape singkong yang dibuat tidak hanya dijual dalam bentuk bahan setengah jadi.

3. Memberdayakan masyarakat untuk meningkatkan nilai ekonomis dari tape singkong yang dibuatnya

Harapan tim pengabdi, kegiatan pembuatan produk olahan berbahan dasar tape singkong dapat terus berlangsung, dan setiap produknya dapat menjadi produkproduk unggulan dari Desa Karangsari.

\section{UCAPAN TERIMAKASIH}

Diucapkan terimakasih yang sebesar-besarnya atas terlaksananya kegiatan pengabdian kepada masyarakat ini, terutama kepada :

1. Lembaga Penelitian dan Pengabdian Masyarakat Universitas PGRI Banyuwangi.

2. DRPM Ristekdikti.

3. Kepala Dusun Mangli dan Kepala Desa Karangsari Kecamatan Sempu Kabupaten Banyuwangi.

4. Pihak-pihak lain yang terkait. 


\section{DAFTAR PUSTAKA}

Chan, H. T., JR. 1983. Handbook of Tropical Foods. Marcel Dekker Inc. New York and Bassel

Fitri, W. 2008. Uji Kadar Protein Tape Singkong (Manihot utilissima) dengan Penambahan Sari Buah Nanas (Ananas comosus). Skripsi. Fakultas Keguruan dan Ilmu Pendidikan. Universitas Muhammadiyah Surakarta.

Direktorat Gizi Depkes. RI. 1981. Daftar Komposisi Bahan Makanan. Jakarta: Bhratara Karya Aksara.

Direktorat Gizi Departemen Kesehatan RI. 1992. Daftar Komposisi Bahan Makanan. Bhartara Karya Aksara, Jakarta.

Hidayat, N., Padaga, M. C dan Suhartini, S. 2006 .Mikrobiologi Industri. Yogyakarta: Andi Offset 